\title{
Analisis Dampak Pemanfaatan Vertikultur terhadap Proses Pembelajaran di SMP N 1 Kartasura
}

\author{
Firda Nur Fatta ${ }^{*}$ ), Merselena ${ }^{2)}$, Mutiara Ilmi ${ }^{3)}$, Ariyanto4) \\ 1,2,3,4)Universitas Muhammadiyah Surakarta \\ *a610170046@student.ums.ac.id
}

\begin{abstract}
Abstrak:Penelitian ini bertujuan untuk mengetahui dampak pemanfaatan vertikultur terhadap proses pembelajaran di SMP Negeri 1 Kartasura. Lokasi penelitian berada di SMP Negeri 1 Kartasura yang beralamatkan di Jl Adisumarmo 37 Kartasura Rt 04 Rw 02, Ngabeyan, Kecamatan Kartasura, Kabupaten Sukoharjo. Perolehan data dilakukan dengan observasi dan wawancara secara random sampling. Penelitian ini menggunakan metode deskriptif. Hasil penelitian menunjukan pola pemanfaatan lahan SMP Negeri 1 Kartasura beserta kaitannya dengan proses pembelajaran yang ada. Pada SMP ini pemanfaatan lahan yang dilakukan amat bervariasi salah satunya dengan vertikultur yang dilakukan guna melestarikan lingkungan serta memberi kesan asri terhadap lingkungan sekolah. Upaya ini menunjukan kepedulian lingkungan SMP Negeri 1 Kartasura terhadap lingkungan hidup serta terciptanya pembelajaran yangnyaman.
\end{abstract}

Kata Kunci: Vertikultur, Pembelajaran, SMP

\section{PENDAHULUAN}

Pada era modern ini kebutuhan akan penggunaan lahan semakin meningkat, namun hal ini tidak diimbangi dengan adanya lahan yang luas. Lahan di daerah perkotaan cenderung lebih padat dan banyak digunakan penduduk. Berbeda lagi dengan di desa, lahan pekarangan dapat dimanfaatkan untuk berbagai tujuan, misalnya sebagai warung hidup dan apotik hidup, menambah pendapatan keluarga, menyediakan bahan-bahan bangunan, dan memberikan keindahan dilingkungan tempat tinggal (Sukanata, dkk, 2016; 1). Tak dipungkiri pertumbuhan penduduk yang kian meningkat menyebabkan kebutuhan akan lahan juga semakin meningkat. Pada daerah perkotaan, kini semakin jarang ditemui taman - taman hijau. Hal ini dikarenakan kebutuhan akan lahan yang semakin pesat. Letak SMP Negeri 1 Kartasura yang terletak di daerah kota juga mempengaruhi penggunaan lahan yang ada. Pihak SMP Negeri 1 Kartasura harus memutar otak guna menghasilkan produk pengelolaan lahan dengan kondisi lahan perkotaan yang semakin sempit namun tuntutan penggunaan yang begitu besar. Lahan yang tidak memadai untuk melakukan pertanian karena banyak kebutuhan lain yang harus menjadi prioritas seperti ruang-ruang kelas maupun tempat parkir. Adanya penggunaan lahan ini yang kemudian menimbulkan pikiran untuk membuat pola pemanfaatan lahan sempit untuk taman hijau yakni dengan vertikultur.

Kebutuhan akan lahan hijau tentu tak dapat dianggap sebagai hal yang remeh. Lahan hijau tentu menjadi kebutuhan penting bagi 
makhluk hidup. Adanya lahan hijau ini juga dapat mendukung adanya kegiatan belajar-mengajar yang nyaman dan kondusif. Pemanfaatan lahan yang baik tentu dapat terjadi jika seluruh warga sekolah baik dari siswa, guru hingga staff yang ada mau berkomitmen untuk memanfaatkan lahan yang ada menjadi terkelola secara baik. Komitmen ini diperlukan untuk menjaga program vertikultur ini agar terus berlangsung dan bukan hanya gebrakan semata. Teknik vertikultur merupakan cara bercocok tanam dengan susunan vertikal atau ke atas menuju udara bebas. Untuk media vertikultur juga biasanya disusun secara vertikal juga. Penempatan media tanam biasanya menggunakan kaleng, paralon, riul, ataupun papan kayu yag dapat digunakan sebagai alternatif tempat media tanam. Sistem budidaya pertanian secara vertikal ini merupakan konsep penghijauan yang cocok untuk daerah dengan lahan terbatas (Susilowati,dkk, 2016:4).

Adapun sistem pertanian vertikultur adalah sistem budidaya pertanian yang dilakukan secara vertikal tau bertingkat. Teknik yang digunakan sangat sederhana namun butuh ketelatenan dalam pemeliharaan. Ada beberapa tipe vertikultur yakni dengan media botol, paralon dan bambu. Beberapa jenis sayuran yang dapat ditanam dalam budidaya ini yaitu selada, sawi, seledri, bayam dan kangkung (Widarto, 2016). Adanya vertikultur berpotensi menjadi suatu pengelolaan lahan yang baik. Hal ini juga menunjukan kemampuan SMP Negeri 1 Kartasura dalam pemanfaatan lahan perkotaan yang terbilang sempit. Pengelolaan lahan yang baik tentu mencerminkan kondisi sekolah yang teratur. Pemanfaatan ini juga tentu berkaitan dengan dampak-dampak yang dapat ditimbulkan melalui vertikultur. Potensi adanya pemanfaatan saling berhubungan dan dapat terjalin baik dengan adanya kegiatan pembelajaran serata kenyamanan lingkungan sekolah.

Pada dasarnya teknik bercocok tanam vertikultur tidak jauh berbeda dengan bercocok tanam konvensional, hanya cara meletakkan/menyusun tanamannya saja yang berbeda (Liferdi dkk, 2016). Lahan yang digunakan untuk vertikultur ini tidak perlu luas asalkan dapat digantungi pot- pot bunga dan dirawat secara baik maka akan membuahkan hasil yang baik pula. Upaya ini dilakukan dengan membudidayakan berbagai jenis tanaman sesuai kebutuhan pangan keluarga seperti aneka umbi, sayuran, buah. Vertikultur yang tidak begitu memakan banyak tempat tentu sangat cocok bila diterapkan di SMP Negeri 1 Kartasura yang terletak diperkotaan dengan adanya keterbatasan lahan pertanian.

Berdasarkan rumusan masalah di atas dapat disusun tujuan penulisan sebagai berikut : (1) Mengetahui pentingnya pemanfaatan lahan di SMP Negeri 1 Kartasura. (2) Mengetahui sikap yang penting dalam pengembangan pemanfaatan lahan di SMP Negeri 1 Kartasura. 
(3) Mengetahui pola pemanfaatan lahan secra efektif dan efisien dan dampaknya terhadap pembelajaran.

\section{METODEPENELITIAN}

Jenis penelitian ini menggunakan metode kualitatif. Metode kualitatif berupa panduan kuisoner, observasi dan wawancara karena bersifat lebih subjektif.

\section{Prosedur Penelitian}

Prosedur penelitian merupakan langkah-langkah yang digunakan sebagai alat pengumpulan data serta dapat menjawab pertanyaan-pertanyaan dalam penelitian. Menggunakan metode dengan analisis kualitatif, sedangkan untuk teknik pengumpulan sampel dengan menggunakan metode random sampling.

\section{Tahapan persiapan}

Penelitian ini diawali dengan tahap persiapan dengan orientasi dan pengkajian data pustaka.

\section{Pengujian instrumen penelitian}

penelitian di uji dengan menggunakan uji validitas dan uji reabilitas. Populasi penggujian ini dilakukan di masing-masing keles yang ada di lingkunga SMP N 1 Kartasura. Alasan pemilihan lokasi karena terkena teknik vertikultur banyak ditemukan disekitar kelas.

\section{Observasi lokasi}

Observasi lokasi dilakukan untuk mendapatkan informasi dan data-data meliputi data perubahan penerapan pemanfaatan lahan melalui sistim vertikultur di lokasi penelitian.

Data kuantitatif didapatkan dengan cara menggunakan instrumen penelitian berupa kuisoner dan data kualitatif menggunakan panduan wawancara.

\section{Subjek Penelitian}

Subjek yang digunakan pada penelitian ini adalah siswa SMP N 1 Kartasura terkait dengan pemanfaattan lahan vertikultur. Sampel pada penelitian ini meliputi siswa kelas VIII A, VIII B, VIII C, VIII D.

\section{HASIL DAN PEMBAHASAN}

Keterbatasan lahan yang ada di SMP N 1 Kartasura menjadi hambatan untuk mengaktualkan potensi lahan hijau yang ada. Adanya keterbatasan ruang hijau dapat mnyebabkan kondisi di SMP ini menjadi panas dan tidak begitu ASRI. Hal yang dapat dilakukan adalah dengan melakukan penanaman tumbuh - tumbuhan dengan sistem vertikultur. Hal ini merupakan cara tanam menggunakan media pot atau peralon yang disusun secara vertikal maupun diganung.

Dari penelitian ini dapat diketahui banyaknya kelebihan sistem vertikultur bagi sekolah, terutama SMP N 1 Kartasura ini sendiri. Kelebihannya adalah sebagai berikut : (1) Efisiensi penggunaan lahan pada SMP N 1 Kartasura. (2) Penghematan pemakaian pupuk dan air. 
(3) Menanamkan jiwa peduli lingkungan pada peserta didik. (4) Meningkatkan.

Selain itu dampak yang timbul terhadap lingkungan sekitar SMP N 1 Kartasura juga mulai terlihat dari adanya penghijauan, lingkungan yang asri, terpenuhinya sirkulasi udara bersih dikitaran kelas. Hal ini sesuai dengan kata-kata yang menjadi unggulan di SMP N 1 Kartasura yakni bersih hati, bersih pikir dan bersih lingkungan. Apa yang ada tentu telah menjadi implementasi dari hal tersebut. Adanya keberhasilan penanaman dengan sistem vertikultur ini juga tak lepas dari komitmen bersama semua warga sekolah uuntuk ikut andil dalam menjaga ke indahan sekolah mereka sendiri.

Menurut Widyastuti (2016:55) halaman sekolah merupakan salah satu tempat belajar yang mendukung dan ideal untuk bisa dimanfaatkan dalam kegiatan proses belajar mengajar, khususnya mengenai lingkungan. Adanya vertikultur di SMP N 1 Kartasura ini tak hanya berdampak bagi lingkungan saja. Dari penelitian yang kami lakukan dapat diketahui bahwa dengan adanya penghijauan melalui veritikultur ternyata juga berdampak pada kegiatan belajar mengajar. Dalam hal ini kegiaan belajar menjadi lebih efektif karena peserta didik menjadi kondusif dan lebih mudah menerima pemlajaran yangg disampaikan ketika kondisi sekitar begitu, mendukung, dalam artian lingkungan tenang, adem, segar dan nyaman, dengan begitu peserta didik akan lebih terfokus pada pembelajaran.

Berbeda dengan temuan kelas yang dapat dikatakan baru direnovasi dan belum diterapkan sistem vertikultur ini. Kondisi lingkungan kelas lebih terasa pengap dan panas, hal ini menggangu konsentrasi belajar anak, kemudian anak mudah lelah, tidak nyaman, bahkan ada yang kipas-kipas dan menjadikan mereka tidak fokus pada pembelajaran. Karenanya dibutuhkan tekat dan komitmen bersama dalam penanaman mengunakan sistem vertikultur ini, agar suasana pembelajaran di kelas dapat berlangsung secara kondusif, sehingga ilmu yang disampaikan dapat diterima secara efektif dan efisien.

Perubahan dan perkembangan pada lingkungan perkotaan mengenai tata guna lahan sangat penting dilakukan. Hal ini tentu berpengaruh terhadap berkurangnya lahan hijau di lingkungan seitar. Institusi sekolah baiknya mengerti tindakan yang harus dilakukan untuk dapat menjaga lingkungan sekolah yang ada demi memenuhi kebutuhan sekolah akan lahan hijau. Apa yang dilakukan SMP N 1 Kartasura ini dapat menjadi contoh sistem tanam yang kreatif pada daerah yang minim akan lahan.

Pemanfaatan lahan hijau yang baik tentu akan mendukung mutu dari sekolah itu sendiri. Lahan hijau di sekolah secara tidak langsung juga berkaitan denga pembelajaran yang berlangsung pada siswa. Dengan tujuan mewujudkan manusia yang cerdas, dan berkehidupan yang damai tanpa mengesampingkan kondisi lingkungan menjadikan 
pelaksanaan vertikultur ini menjadi penyempurna yang seimbang di SMP N 1 Kartasura.

Hal ini juga mendidik siswa sejak dini betapa pentingnya pemanfaatan lahan terutama untuk penghijauan. Agar tercipta SDM yang memiliki kesadaran serta tanggung jawab akan pentingnya menjaga lingkungan hidup. Kegiatan pembelajaran juga harus berkesinambungan dengan hal - hal yang ada di lingkungan sekolah. Terciptanya pembelajaran yang efektif tak lepas dari komitmen bersama seluruh warga sekolah.

\section{KESIMPULAN}

Berdasarkan hasil analisis, peneliti mengambil beberapa simpulan yang terdiri dari kesimpulan umum dan simpulan khusus. Simpulan umum penelitian ini adalah budaya vertikultur memberikan pengaruh pada proses pembelajaran yang berlangsung di SMP N 1 Kartasura. Adapun simpulan khusus penelitian ini : (1) sistem tanam dengan cara vertikultur yang dilaksanakan di SMP N 1 Kartasura ini berdampak baik pada sistem pengelolaan lahan sempit di perkotaan. (2) sistem vertikultur di SMP N 1 Kartasura memang belum terlaksana sepenuhnya terutama pada gedung - gedung baru. Namun dengan gerakan vertikultur mampu memperhijau setidaknya $75 \%$ lingkungan SMP N 1 Kartasura dan berdampak baik dalam proses pembelajaran.

\section{DAFTAR PUSTAKA}

Andi Dwi. 2018. Teknik Vertikultur pada Lorong Garden. Jurnal Pendidikan Teknologi Pertanian. Vol.4.

Azrul, Azwar. 1995. Pengantar Ilmu Kesehatan Lingkungan. Jakarta : Mutiara Sumber Widya.

Departemen Pendidikan Nasional. 2013. Kegiatan Belajar Mengajar yang Efektif. Jakarta.

Juli Sumirat. 2011. Kesehatan Lingkungan. Yogyakarta: Gajah Mada University Perss.

Kementerian Pertanian RI Badan Ketahanan Pangan. 2013. Pedoman Pelaksanaan (Gerakan Percepatan Penganekaragaman Konsumsi Pangan P2KP). Jakarta: Kementrian RI.

Liferdi, L dan Cahyo Saparinto. 2016. Vertikultur Tanaman Sayur. Jakarta: Penebar Swadaya.

Rawiniwati, Wayan dkk. 2012. "Petanian Perkotaan dengan Sistem Vertikultur".

Sukanata, I Ketutu, dkk. 2016. Faktor-Faktor yang Mempengaruhi Pemanfaatan Lahan Pekarangan dalam Kegiatan Kawasan Rumah Pangan Lestari (Studi Kasus di KWT Dewi Srikandi Desa Cipanas Kecamatan Dukupuntang Kabupaten Cirebon). Jurnal 
Agrijati. 28 (1): 1-16.

Susilowati, Dewi, dkk. 2016. Vertikultur: Iovasi Pertanian di Kawasan Urban. Geospasial. 14 (1):2-7.

Widarto. L. 2016. Vertikultur Bercocok Tanam Secara Bertingkat. Jakarta: Penebar Swadaya.

Widyastuti, Titiek \& Rini Juni Astuti. 2016. Penataan Sekolah sebagai Ekoedukasi. Jurnal Berdikari. 4 (1): 54-62. 